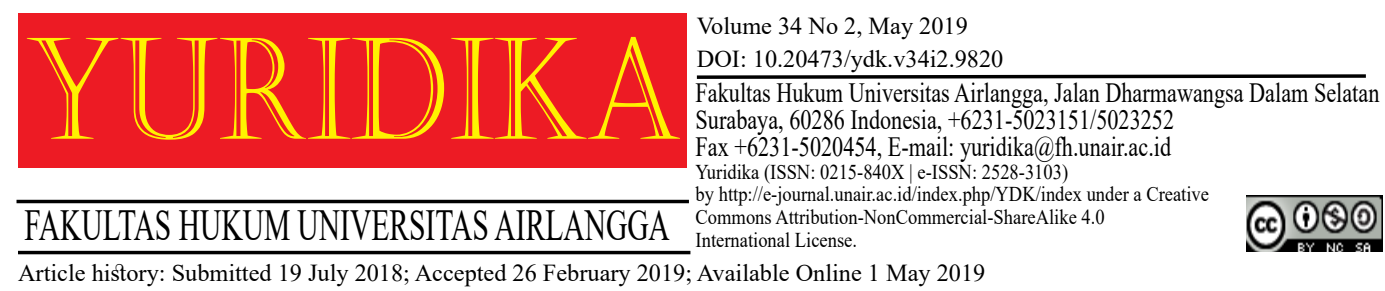

\title{
Analysis of the Constitution Court Verdict Number 46/PUU-XIV/2016 about Morality Criminal
}

\author{
Ansori and Muhammad Fuad Zain \\ ans.iainpurwokerto@gmail.com \\ IAIN Purwokerto
}

\begin{abstract}
Indonesian Family Loves Alliance see that Penal Code in article 284, 285 and 295 related to adultery, rape and molestation (sacrilege or abuse) which is contrary to religious values and the morale of the Indonesian people deliver to sue the Constitutional Court through judicial review with results was rejected. Five judges with judicial restraint argue that the State must protect rights and freedoms, not vice versa, but four others with judicial activism argue that the State must protect the rights of citizens by referring to the living law with develops in society. With no expansion of the meaning of the article a quo then LGBT, adultery, rape and molestation can not be convicted. This verdict has been troubling most of Indonesians who wants a change in the legal system, considering the legislative process that began in 1963 until now did not come to fruition. So the People's Consultative Assembly and the President as a positive legislator are required to immediately revise the laws and regulations in accordance with religious norms and common laws that develops in society to avoid the violence or vigilante action which actually harms the community itself.
\end{abstract}

Keywords: Penal Code; Judicial Review; Judicial Restraint; Judicial Activism.

\section{Introduction}

After 21 court sessions, the Constitutional Court finally issued decision No. 46/PUU-XIV/2016 on December 14, 2017, regarding the application to expand decency offenses in the criminal code related to adultery (Article 284), rape (Article 285), and obscene acts (Article 292). In judgment: "Reject the petitioners in its entirety". ${ }^{1}$ This decision ended with dissenting opinions among constitutional justices there were Arief Hidayat, Usman Anwar, Wahiduddin Adams, and Aswanto. With the rejection of the petition for an article a quo, some people assumed that "the

\footnotetext{
${ }^{1}$ Putusan Mahkamah Konstitusi Nomor 46/PUU-XIV/2016 2017 [453].
} 
Constitutional Court seemed to legalize adultery and LGBT". But it was denied by legal experts, former head of justice the Constitutional Court Mahfud MD. ${ }^{2}$

It was different, the verdict No. 46/PUU-VIII/2010, case of Aisyah Mochtar called Machica daughter of Mochtar Ibrahim, in judgement: "To grant the petitions in part" which gave the status of a child born (Muhammad Iqbal Ramadhan) in illegal marriage still had civil relationship with his mother and his mother's family and with men as his father which could be proven based on science and technology and/ or other evidence according to blood relations, including civil relations with his father's family. This decision did not mean to legal the adultery, but it was a form of the Court's Interpretation ( $i j t i h \bar{a} d)$ to protect the rights of a child born which did not have recorded by the state as stated by Nurul Irfan. ${ }^{4}$

With the rejection of judicial review on article a quo, the expansion of the meaning of adultery, rape, and obscene acts that occur in the community could not be criminalized and had a vacuum of the law. Which a case of immoral by a pair of lovers at the Sraten Mosque Salatiga ${ }^{5}$ which exposed by press could be criminalized because there were no rules governing. Whereas mala in se on society ideally it could be made judges to consider moral reading or living law. Quote Agiwinata, law comes from moral and goodness, according to Peter Mahmud Marzuki's love and attitude are the foundation of people's lives. ${ }^{6}$ This feeling of love and attitude is called moral, where the morality and goodness must always grow and develop in our country.

Based on background of research, the author would like to discuss further more about analysis of the Constitution Court from from the view of normative law and phenomenas of community which required of the change in the legal system

\footnotetext{
${ }^{2}$ Kristian Erdianto, 'Mahfud MD: Yang Kurang Paham, Menuduh MK Perbolehkan Zina Dan LGBT' (Kompas, 2017) < https://nasional.kompas.com/read/2017/12/17/16235281/mahfud-md-yangkurang-paham-menuduh-mk-perbolehkan-zina-dan-lgbt?page=all $>$ accessed 13 January 2018.

${ }^{3}$ ibid.

${ }^{4}$ Fat-Ash, 'Putusan MK Berpengaruh Pada Hukum Waris' Hukum Online (Jakarta, February 2012).

${ }^{5}$ Yasmine Aulia, 'Kronologi Penangkapan Sepasang Muda-Mudi Mesum Di Dalam Masjid Di Tuntang' Tribun Jateng (Semarang, April 2018).

${ }^{6}$ Weldy Agiwinata, 'Konvensi Ketatanegaraan Sebagai Batu Uji Dalam Pengujian Undang Undang Di Mahkamah Konstitusi' (2014) 29 Yuridika.[149].
} 
especially the Colonial Penal Code become the penal code in accordance with religious values and local values which develop in society.

The research method is a normative legal, which is a study of legal principles carried out from the Constitution Court Verdict No. 46/PUU-XIV/2016, which aims is to resolve legal problems that occur due to the rejection of a decision. It is expected this article will contribute to build a criminal law process, which is still in the legislative process by the People's Consultative Assembly. The author tries to dissect the mindset of the judges in concluding where five judges use judicial restraint and four judges use judicial activism. This study is not five vs four but will try to dismantle theories in legal exploration. The author uses descriptive analytics that is intended to provide data as closely as possible related to other conditions or symptoms through describing facts, situations and conditions of the object of research studies, then from these facts relate to discussed, analyzed, and conclusions to be drawn to answer the existing problems.

\section{History of Establishment of the Constitutional Court}

The Constitutional Court of the Republic of Indonesia is a new state institution in Indonesian constitutional system according with the amendment of The 1945 Constitution. The Constitutional court is one of the perpetrators of the Ministry of justice as referred in The 1945 Constitution. The genesis of the Constitutional Court is inseparable from the history of judicial review or called constitutional review by the Supreme Court to cancel a law because of its content is against the Constitution. The first judicial review in the United States was carried out by John Marshall in 1803, which had a very important influenced on other countries, including Indonesia. ${ }^{7}$

The idea of establishing the Constitutional Court was reformed began at the second session of Ad Hoc I Working Committee of People's Consultative Assembly of the Republic of Indonesia after all members of the Indonesian People's

${ }^{7}$ Nanang Sri Darmadi, 'Kedudukan Dan Wewenang Mahkamah Konstitusi Dalam Sistem Hukum Ketatanegaraan Indonesia' (2015) 2 Pembaharuan Hukum.[258]. 
Consultative Assembly's Working Committee conducted comparative studies in twenty-one states regarding the constitution in March-April 2000. This idea did not appear at the first amendment to The 1945 Constitution, even not a single faction in the People's Consultative Assembly proposed it. It seems that the members of the People's Consultative Assembly were greatly affected by their findings in the comparative study. Nevertheless, at the annual session of the People's Consultative Assembly in August 2000, the draft formula regarding the Constitutional Court still in the form of several alternatives and did not final.

The history of establishment the Constitutional Court in Indonesia began with adoption of an idea of the Constitutional Court in constitutional amendments carried out by People's Consultative Assembly in 2001 as formulated in the provisions of Article 24 paragraph (2), Article 24C, and Article 7B of the Third Amendment to The 1945 Constitution which was ratified on November 9, 2001. After ratification of the Third Amendment to The 1945 Constitution, in order to wait for the formation of the Constitutional Court, People's Consultative Assembly determined the Supreme Court would carry out functions of the Constitutional Court temporarily as determined in Article III of transitional rules of Fourth Amendment of The 1945 Constitution.

People's Consultative Assembly and government then drafted a law concerning the Constitutional Court. After depth discussion, People's Consultative Assembly and government agreed to the establishment of law No. 24 of 2003 concerning the Constitutional Court on August 13, 2003, and was ratified by President. Two days later, on August 15, 2003, President issued decision Presidential Decree No. 147/M of 2003 and inaugurated constitutional justices for the first time followed by the oath of office for constitutional justices on August 16, 2003.

The Constitutional Court has four authorities and one obligation as stipulate in The 1945 Constitution. The Constitutional Court has authority to adjudicate at the first and last level, whose the decisions are final and can not be sued, there are: (1) Examine laws against The 1945 Constitution; (2) Decide authority dispute of state institutions; (3) Decide dissolution of political parties; (4) Decide disputes 
of results general elections; (5) The Constitutional Court oblige to give a decision on the opinion of People's Consultative Assembly that the President and/ or Vice President are alleged have committed impeachment.

The composition of the Constitutional Court as explained in article 4: (1) Constitutional Court has nine members of constitutional justices stipulate by a Presidential Decree; (2) The composition of Constitutional Court consists of a Chairperson concurrently a member, a Deputy Chairperson concurrently a member, and seven members of the constitutional justices; (3) The Chairperson and Deputy Chairperson are elected for three years; (4)Before Chairperson and Deputy Chairperson are elected as referred to in paragraph three, the election meeting for Chairperson and Deputy Chairperson are led by the oldest; and (5) Provisions regarding the procedure for selecting the Chair and Deputy Chairperson as referred to in paragraph three should be further stipulate by the Constitutional Court. The Constitutional Court law contains rules regarding material law and formal law. Overall, the law consists of 88 articles and most of them are provisions that regulate formal law. The material law amounts to 30 articles, which are regulated in articles 1 to 27 and article 86 to 88 . While formal law consists of 58 articles, from article 28 to article 85 . In percentage, its consists of the material law are 34 percent and the formal law are 66 percent.

Procedural law at the Constitutional Court, there are two types of proceedings, namely contentious procesrecht and non contentious procesrecht. Contentieus procesrecht was a procedural law that has a character of adjudicating and resolving a dispute, which involves at least two opposing parties. Whereas non contentieus procesrecht or also called voluntary procesrecht is a procedural law which it does not contain resolution a dispute because it only involves one party called the applicant. The process of proceedings at the Constitutional Court, in addition, use contentious procesrecht, there was nondispute as volunteer.

\section{The Problem of the Indonesian Penal Code}

The penal code is a legacy of Dutch colonialism, which is the result of a concordance from Wetboek van Strafrecht since 1886. In short history, in 1642 
Joan Maetsuycker, the former Hof van Justitie in Batavia, was tasked by Governor General van Diemen to complete a collection of placards named Statuten van Batavia. In 1650, placards were authorized by Heeren Zeventien, then 1848 Intermaire Strafbepalingen was established and then 1866 Wetboek van Strafecht was enforcing in Indonesia. ${ }^{8}$

Enforcement of the Indonesian penal code based on law number one of 1946 for Java and Madura and the enforcement to entire territorial of the Republic of Indonesia was carried out on September 20, 1958, with the enactment of law No. 73 of 1958. The wishes of the Indonesian people to renew the Criminal Code had been born since 1963. In the National Law Seminar, a lot of legal experts such as Roeslan Saleh, Moeljatno, and Kadarusman had stated the need for a new Criminal Code. The Indonesian legal experts considered Indonesian Code Penal that used at 1963 was born in 1886 had many holes, was old and had to be made.

Barda Nawawi Arief noted that Roeslan Saleh explained in a workshop on the Codification of Criminal Law Chapters (Book II) hold by the BPHN Ministry of Justice on April 23-25, 1985 in Jakarta underlined the views of Oemar Senoadji, that to determine the content or material of morale delict must be sourced and back to religious and community morale. Determination of morale delict must also be oriented towards national moral values that had been mutually agreed upon and also pay attention to moral values that live in the community to be made to law product. ${ }^{9}$

\section{The Constitutional Court as Constitutional Interpretation}

Albert H. Y. Chen used term constitutional interpretation which was distinguished from the interpretation of statutes. The constitutional interpretation was the interpretation of the provisions contained in the constitution or the basic law, or the interpretation of the basic law was inseparable from judicial review

\footnotetext{
${ }^{8}$ Andi Hamzah, Asas-Asas Hukum Pidana (2nd edn, Rineka Cipta 1994).[16].

9 Barda Nawawi Arief, Kebijakan Hukum Pidana; Perkembangan Penyusunan Konsep KUHP Baru (Kencana Prenada Media Group 2014). [95].
} 
activities. ${ }^{10}$ Chen stated that American experience showed that constitutional interpretations could not be separated from a review of the constitutionality of government actions, specifically the legislative law. Judicial review first established by the American Supreme Court in Marbury vs. Madison (1803). ${ }^{11}$

Interpreting the constitution, its mean giving meaning or meaning to a term or set of terms in the formulation of an article or paragraph. Usually did by describing or explaining the purpose of something that was considered unclear. In addition, interpreting the constitution or law means giving information or explanation so that the meaning or meaning could be understood. ${ }^{12}$

Sudikno Mertokusumo and A. Pitlo argued that interpretation was one method of legal discovery that gave a clear explanation text of the law, so the scope of rules could be established in certain events. Interpretation of the judge was an explanation that must lead to an implementation that could be accepted by the citizen regarding legal regulations against concrete events. This method of interpretation was a tool to find out the meaning of the law. The justification lied use to implement concrete provisions and not for the method itself. ${ }^{13}$

Regarding to the size of clarity in the regulations of laws (including the constitution or the Basic Law), Satjipto Rahardjo quoted Montesquieu's opinion on criteria for drafting legislation as follows: (1) The style of narrative should be compact and simple; (2) Regulations should limit to themselves to real and actual by avoiding metaphorical and hypothetical; (3) Regulations should be not too high, because it was intended for people with only middle intelligence; the rule was not an exercise in the use of logic, but only simple reasoning that could be done by ordinary people; (4) Do not dispute the main, restrictions or modifications, except in matters that were very necessary; (5) Regulations might

\footnotetext{
${ }^{10}$ Albert H. Y. Chen, The Interpretation of the Basic Law-Common Law and Mainland Chinese Perspectives (Hong Kong Journal Ltd 2000).[1].

${ }^{11}$ ibid.

${ }^{12}$ Rosjidi Ranggawidjaja, Wewenang Manafsirkan Dan Mengubah Undang-Undang Dasar (Citra Bakti Akademika 1996).[114].

${ }^{13}$ Sudikno and A. Pitlo Mertokusumo, Bab-Bab Tentang Penemuan Hukum (Citra Aditya Bakti 1993).[13].
} 
not contain arguments: it was dangerous to provide detailed reasons for a rule and open opposition. ${ }^{14}$

There was a view that suggested: interpretation of the constitution was not the same as legal interpretation. Relying on a definition of the constitution on the one hand, and the notion of law, on the other hand, was clear that the definition of the constitution was not the same (analog). Therefore, the constitutional interpretation was not just an analogy with legal interpretation. If the constitution was defined as basic law, the interpretation of the constitution or basic law was only one part of the legal interpretation. Legal interpretation (seen from its legal form - rechtsvorm) could be broadly meaningful, whether interpretations of written law (geschreven recht) and unwritten law (ongeschreven recht). However, in practice, the distinction between constitutional interpretation or legal interpretation could not be drawn explicitly, because when the judge interpreted the constitution, it could not be limited only by making interpretations of written legal norms or according to the text formulation, but it might be interpreted to unwritten constitutional legal norms, such as the principles of general law which were behind the formulation of written legal norms. ${ }^{15}$

Generally, the theory of legal discovery (rechtsvinding) was divided into two: (1) heteronomous rechtsvinding; and (2) autonomous rechtsvinding. Heteronomy rechtsvinding occurred when a judge decided a case and established a law assuming that he was bound by the rules of law that offered to him. Autonomous rechtsvinding means pointing to the contribution of the judge's thought. Judges could provide input or contribution through interpretation methods that were in accordance with the model of logistic legal discovery or through new methods of interpretation such as teleological and evolutionary-dynamical interpretation methods which the judge determined what was he purposed. Teleological and evolutionarydynamical interpretation methods also gave alternative judges the possibility to examine whether the meaning that time was still in accordance with the actual

\footnotetext{
${ }^{14}$ Satjipto Rahardjo, Ilmu Hukum (Citra Aditya Bakti 2006).[94-95].

${ }^{15}$ Muchamad Ali Safa'at, 'Penafsiran Konstitusi' (2011).[61].
} 
development of society. ${ }^{16}$ Quote, Sudikno Mertokusumo stated that interpretation was an explanation that must lead to an implementation that could be accepted by the community regarding legal regulations on concrete events. This method was a tool to find out or discover the meaning of the law. ${ }^{17}$

In addition to the methods above, interpretations could be divided into two types: (1) restrictive interpretation method; and (2) extensive interpretation method. The restrictive interpretation was a limiting explanation or interpretation to explain a provision of the law, that the scope of provisions was limited. The principle that used in this method was a principle of lex certa, that a material of law could not be expanded or interpreted except what was written in law, or in other words a statutory provision could not be given an extension except determined explicitly and clearly according to text law itself. ${ }^{18}$

While extensive interpretation was an explanation that overreach which had set by grammatical interpretation. Quote Sudikno Mertokusumo and A. Pitlo had identified several methods of interpretation commonly used by judges as follows: grammatical interpretation; teleological or sociological interpretation; systematic or logical interpretation; historical interpretation; comparative or comparative interpretation; and futuristic interpretation. ${ }^{19}$

According to Chen, as quote Bobbitt, there are six types of constitutional interpretation methods; textual interpretation; historical interpretation; doctrinal interpretation; prudential interpretation; structural interpretation; and ethical interpretation. ${ }^{20}$ Although a variety of constitutional interpretations was various in essence of interpreting divided into two major groups: interpreting originalism, which used the original intent approach (including historical approaches) to constitutional legal norms, and nonoriginalism.

\footnotetext{
16 ibid.

${ }^{17}$ ibid.

${ }^{18}$ ibid.

${ }^{19}$ Aris Hardinanto, 'Manfaat Analogi Dalam Hukum Pidana Untuk Mengatasi Kejahatan Yang Mengalami Modernisasi' (2016) 31 Yuridika.[220].

${ }^{20}$ Albert H. Y. Chen (n 10). [5].
} 


\section{Article 284, 285, and 295 in Indonesian Penal Code}

The research was conducted by Bisariyadi and friends related verdicts the Constitution Court in period 2003-2015 found three groups of criteria: (1) Enough use (quote) the articles in constitution as a basis for testing (without elaborating on the meaning behind the text); (2) Mention the principles or constitutional values as a basis for testing (without specific the articles in constitution which were used as test stones); (3) Did not mention the basic norm testing (the panel judgment judge directly to conclude the norms tested not conflict with The 1945 Constitution. ${ }^{21}$

Table 1. The Articles of Indonesia Penal Code Tested by The 1945 Constitution

\begin{tabular}{ll}
\hline \multicolumn{1}{c}{ Article Tested } & \multicolumn{1}{c}{ Test Stones } \\
\hline $\begin{array}{l}\text { Article 284, 285, 295 in the } \\
\text { Indonesian Penal Code }\end{array}$ & Article 29 paragraph (1), Article 28D paragraph (1), Article 28B \\
& paragraph (1) and paragraph (2), Article 28C paragraph (2), Article \\
& 28G paragraph (1) and paragraph (2), Article 28H paragraph (1 ), \\
& Article 28J paragraph (1) and paragraph (2) of The 1945 Constitution \\
\hline
\end{tabular}

In accordance with Court's judgments contained in paragraph (3). ${ }^{22}$ that the petition of the petitioners was no longer merely pleading with the Court to give a certain meaning to the norms of the law petitioned for review in a quo article, nor was it merely to expand definition of norms contained in article a quo, but actually formulates a new criminal act. ${ }^{23}$ Eliminating certain phrases and/ or adding new meaning to a norm of criminal law, means changing the character of the law (wederrechtelijkheid), without making changes or adjustments in its criminal threat (form) and the form of criminal imposition (staffmodus) could not be accepted by legal reasoning in designing a norm of criminal law. ${ }^{24}$

According to the judges, if a quo petition was granted would conflict with the principle of legality which must be strictly applied in criminal law. The principle was contained in adagium nullum delictum, nulla poena sine praevia lege punali which contains four meanings as one roundness: nullum crimen, nulla poena sine lege praevia; nullum crimen, nulla poena sine lege scripta; nullum crimen, nulla poena sine lege certa; and nullum crimen, nulla poena sine lege stricta. Although there

\footnotetext{
${ }^{21}$ Bisariyadi, 'Penafsiran Konstitusi Dalam Pengujian Undang-Undang Terhadap UUD' (2016).[viii].

${ }^{22}$ Constitutional Court No. 46/PUU-XIV/2016 (n 1).[429].

${ }^{23}$ ibid. [439].

${ }^{24}$ ibid.
} 
was a view that the Court's verdict was equivalent to the law, the three principles can be represented, but the principle nullum crimen, nulla poena sine lege stricta; clearly not fulfilled. That principle had understood that the provisions contained in criminal law must be interpreted strictly. From here came the understanding that in criminal law prohibited from using an analogy. ${ }^{25}$ Furthermore, the panel of judges explained that Article 284, Article 285 and Article 292 were incomplete or not fully able to accommodate the aspirations of community (living law) did not mean that the norms of the law were contrary to The 1945 Constitution (unconstitutional) but the majority of the Indonesian people see that the contents of the Criminal Code are very contrary to religious values, especially Islamic values, ${ }^{26}$ however the role of legislators who must renew, because the Court was a negative legislator, not as a positive legislator. ${ }^{27}$

Regarding the Court's verdict, there were four judges having different opinions as called dissenting opinion: Arief Hidayat, Anwar Usman, Wahiduddin Adams, and Aswanto. They had opinions as follows:

1. Pancasila was the source of all sources of state law. Placing Pancasila as the source of all sources of state law was in accordance with the Preamble of The 1945 Constitution of the Republic of Indonesia. In Pancasila, the value of divinity is read and interpreted hierarchically. The Godhead value was the highest value because it involves absolute values, all good values are derived from this value. An action was said to be good if it did not conflict with God's values, rules, and laws. Borrowing Soekarno statement, God's values was a cultural value and godhead. Its mean, ethical values of God that were extracted from the prophetic values of the religions and beliefs in the nation that were liberating, glorifying justice and divine brotherhood, and tolerant that gave

\footnotetext{
${ }^{25}$ ibid. [440].

${ }^{26}$ Lalu Nugraha, 'Juridical Analysis of MK Decision No: 46/PUU-XIV/2016 Concerning Expansion of Zina and LGBT Meanings’ (2018) 2 International Journal of Humanities, Religion and Social Science.[62-80].

${ }^{27}$ Putusan Mahkamah Konstitusi Nomor 46/PUU-XIV/2016 (n 1).[441].
} 
spirit to mutual cooperation in social ethics in the life of the nation and state. ${ }^{28}$

2. Mohammad Hatta revealed, precepts of Godhead became the basis which led to the path of truth, justice, goodness, honesty, and brotherhood. precepts of Godhead invited the Indonesian people to develop social ethics in publicpolitical life by fostering a sense of humanity and unity, developing consultations and social justice. The first principle of Pancasila, God the one and only God, not the principle that enters the faith space of the religious community, but it was a principle of living together in a country in a society with a diversity of religions and beliefs. Godhead was interpreted in the context of practical life, a life characterized by how divine values were practiced in daily life, such as being fair to others, saying and acting honestly, and connecting with friends, so that divisions between people can be avoided, God's values not in the meaning of too theological and philosophical.

3. The 1945 Constitution was a basis law in legislation. Basis law was the basis norm as the formation of legislation which a legal source for establishment of legislation under The 1945 Constitution. Based on Article 29: (1) The State is based on the one Godhead; (2) The State guarantees the independence of each resident to embrace his own religion and to worship according to his religion and belief. Article 18B Paragraph (2) The State recognizes and respects customary law units along with their traditional rights insofar as they were still alive and in accordance with the development of society and the principles of the Unitary State of Republic Indonesia, which was regulated by law. This conception affirms that the laws and regulations in Indonesia must always be in line and must not conflict with the basic principles of Godhead and religious and living law values which were in accordance with the development of society and the principles of Republic Indonesia. One of the constitutional rights for each person was fair legal certainty, if the norms of law (Criminal Code Article 284, Article 285 and Article 292) were reduced, narrowed, overreached, and/

${ }^{28}$ ibid. [454]. 
or contrary to the basis of the one Godhead and religious and living law values that were in accordance with the development of society and the principles of the Republic Indonesia, must be declared contrary to The 1945 Constitution (unconstitutional) and did not have binding legal force.

\section{Judicial Restraint Versus Judicial Activism}

Judging verdict of the Constitutional Court No. 46/PUU-XIV/2016 actually the court was divided into two schools; where five judges consist of Maria Farida Indrati, I Dewa Gede Palguna, Suhartoyo, Manahan MP Sitompul, and Saldi Isra used judicial restraint, while four others were Arief Hidayat, Anwar Usman, Aswanto, and Wahiduddin Adams used judicial activism.

Judicial restraint was a developing doctrine in America which was the implementation of application from the principle of power separation. The doctrine of judicial restraint, the court must be able to restrain themselves from tendencies or incentives to act as a Mini Parliament. One of court form action that could be categorized as a parliamentary act was forming a new legal norm when deciding judicial review case. This kind of restraint was based on the court's own awareness that the court was not a primary custodian in the political system in a democratic country. In other words, judicial restraint refused to make the court a "philosopher kings" like Plato's teachings about the state led by philosophers. ${ }^{29}$ A judicial restraint according to Aharon Barak was that judges must as far as possible not form new legal norms in judging a case to create a balance between conflicting social values. In other words, judicial restraint requires the judge to interpret a law by first paying attention to the legal politics that form it. ${ }^{30}$

Robert Posner provided a more assertive understanding of judicial restraint. According to Posner, judicial restraint was an attempt by a judge or court to limit themselves within the framework of the principle of separation of powers. This

${ }^{29}$ Wicaksana Dramanda, 'Menggagas Penerapan Judicial Restraint Di Mahkamah Konstitusi’ (2014) XI Jurnal Konstitusi [618].

30 ibid. 
means that judicial restraint was an effort of the branch of judicial power not to try cases that would interfere with other branches of power. Posner considers that the court was not a "primary custodian" in the political system of a country that can determine social welfare. Therefore, the court was only permitted to try cases that were determined in a limited manner based on the law as limited jurisdiction. Based on this positive opinion, judicial restraint could also be interpreted as structural restraint. Judicial restraint consists of various types of restrictions for the court in judging constitutional matters. The types of restrictions are constitutional restrictions, policy-based restrictions, and doctrine-based restrictions. ${ }^{31}$

Opposing of judicial restraint was judicial activism, this term was first introduced by Arthur Schlesinger in January 1947 in Fortune magazine. Judicial activism is always attached to the context in which the judge makes judges making law in his decision. ${ }^{32}$ Judges tend to implement judicial activism, or commonly referred to as activist judges, were judged to have exercised the judicial discretion which was contrary to general principles, such as the principle that judges only carry out functions to implement laws made by legislators. The judges were considered likely to position themselves as judges who can give consideration to political, social and economic policies.

A positive view of judicial activism usually comes from human rights activists and pro-democracy. They see judicial activism as a legal adaptation to social change by developing principles take from the text of the constitution and existing decisions to implement progressive basic values of the constitution.

M.Vignesh, Saleem Ahmed $^{33}$ concluded the difference between judicial activism and judicial restraint as follows:

1. Judicial activism is the translation of the constitution to advocate for respect and contemporary conditions. Whereas judicial restrictions aim to impede the power of judges in imposing laws;

\footnotetext{
31 ibid.

32 Pan Mohamad Faiz, 'Dimensi Judicial Activism Dalam Putusan Mahkamah Konstitusi' (2016) XIII Jurnal Konstitusi [406].

${ }^{33}$ M.Saleem Ahmed Vignesh, 'A Study on Judicial Activism and Judicial Restrain in Indian Judiciary’ (2017) XX Humanities and Social Science.[85].
} 
2. In judicial restrictions, the court must divert all congressional demonstrations and state bodies unless they abuse the country's constitution. Within legal constraints, the court, for the most part, acknowledged the constitutional explanation by the Congress or several other protected bodies;

3. In restrictions on judicial and judicial activism, judges are required to use their powers to revise the law, especially when other judges do not act. This implies that judicial activism has an extraordinary part in defining social approaches on issues such as the security of an individual's privileges, social equality, deep open quality, and the political stage;

4. Judicial activism and judicial restrictions have a variety of objectives. Judicial restrictions help in protecting adjustments between government, legal, official and administrative branches. In this situation, the judges and court support surveying the current law are contrary to changing existing laws;

5. When discussing the objectives of judicial activism, provide the ability to override certain demonstrations or judgments. For example, the Supreme Court or redrafting court can reverse some past choices if they are disabled. This legal framework also applies as a balanced government and safeguards the three branches of government, legal, official and authoritative from closures that feel strong;

6. Judicial restrictions, the judges must look at the purpose of the bodies governing the law and the contents of the law in making a choice for each development to the dialect of the Constitution must first be carried out with a sacred correction.

Quote Pan Mohamad Faiz, Christopher G. Buck, there were four principles that must be applied by judges in deciding the judicial activism approach: (1) To protect the rights and freedoms of citizens, both expressly and implicitly in the constitution; (2) To provide maximum protection to minority or vulnerable groups who obtain negative impacts from the decision process which was based solely on the consideration of the majority, (3) To restore and protect the constitutional rights of violated citizens, both individually and in groups; and (4) To adjust the development of global justice by using comparison and international law. ${ }^{34}$

Other views on judicial activism are actually accordance with Article 5 of Law No. 48/2009 about Judicial Power which mandates that the constitutional justices and judges must explore, follow, understand the legal values and sense of justice that live in society, then the constitutional judges and judges must follow and take sides legal values and a sense of justice that live in society. With a dissenting

\footnotetext{
${ }^{34}$ Pan Mohamad Faiz, 'Judicial Restraint Vs Judicial Activism' [2017] Mahkamah Konstitusi [8-9].
} 
opinion on the Constitutional Court's verdict No. 46/ PUU-XIV/ 2016 among them, the author classified in table:

Table 2. The Difference Judges on court decisions

\begin{tabular}{|c|c|}
\hline The Majority of Judges & The Minority of Judges \\
\hline Used restrictive interpretation; & Used extensive interpretation; \\
\hline $\begin{array}{l}\text { Used the theory of retributivism, the main } \\
\text { purpose of punishment was retaliation; }\end{array}$ & $\begin{array}{l}\text { Used the utilitarian theory, the basic element } \\
\text { of criminal determination in philosophy was } \\
\text { aiming to prevent; }\end{array}$ \\
\hline $\begin{array}{l}\text { Used heteronomous legal findings, judges were } \\
\text { bound by legal rules; }\end{array}$ & Used autonomous legal invent-ions; \\
\hline $\begin{array}{l}\text { Used literal interpretations that were } \\
\text { interpretations that solely used sentences } \\
\text { sentence of rules as a handle; }\end{array}$ & $\begin{array}{l}\text { Used functional interpretations or free } \\
\text { interpretations; }\end{array}$ \\
\hline $\begin{array}{l}\text { Used grammatical interpretation or interpretation } \\
\text { according to language also called the objective } \\
\text { interpretation method; }\end{array}$ & $\begin{array}{l}\text { Used comparative interpretations, in this case, } \\
\text { the Constitutional Court often used Islamic } \\
\text { law and moral reading in the community or } \\
\text { living law; }\end{array}$ \\
\hline $\begin{array}{l}\text { Used systematic interpretation or logical } \\
\text { interpretation; }\end{array}$ & $\begin{array}{l}\text { Used future interpretations or anticipatory } \\
\text { methods of legal discovery, to explain the } \\
\text { provisions of the act that did not have legal } \\
\text { force; }\end{array}$ \\
\hline $\begin{array}{l}\text { Used doctrinal interpretation, the method of } \\
\text { interpretation carried out by understanding the } \\
\text { rules of the law through a system of precedents } \\
\text { or through judicial practices; }\end{array}$ & $\begin{array}{l}\text { Used teleological or socio-logical } \\
\text { interpretations if the meaning of the law was } \\
\text { determined based on community goals; }\end{array}$ \\
\hline $\begin{array}{l}\text { Used prudential interpretation or interpretation } \\
\text { methods which carried out by finding a balance } \\
\text { between the costs that must be incurred and the } \\
\text { benefits obtained from the application of a certain } \\
\text { rule of law. }\end{array}$ & $\begin{array}{l}\text { Used ethical interpretations, the method } \\
\text { of interpretation constructed from the } \\
\text { type of constitutional thinking that used a } \\
\text { philosophical, aspirational or moral approach. }\end{array}$ \\
\hline
\end{tabular}

\section{Conclusion}

Generally, constitutional judges tend to use judicial restraint compared to judicial activism. In the absence of an expansion of the norms of criminal offenses or criminalization, it is nothing but protecting or restoring constitutional rights and freedoms, rather than limiting the rights and freedoms of citizens (although according to researchers the Court should return to Article 28J paragraph (2) of The 1945 Constitution). The judge who has a dissenting opinion considers that the state must protect the rights of its citizens by referring to the growing living law in Indonesian society. The four judges tend to use futuristic interpretations as a method of legal discovery, thus, this interpretation is more of an ius constituendum 
(law or law that is reported) than ius constitutum (law or law that applies at the present time). In addition, the four judges used comparative interpretation methods or comparisons with Islamic law and customary law as living law in the community. The Constitutional Court was rejected the judicial review on the expansion of meaning in the articles a quo had implications that criminalization of adultery and LGBT cannot be criminalized. There is a vacuum of legal law related to adultery and LGBT which can disturb the community. So the Indonesian Legistilative Assembly and the President as a positive legislator are required to immediately revise the laws and regulations in accordance with religious norms (precepts of Godhead) and common laws that develops in society to avoid the violence or vigilante action which actually harms the community itself.

\section{Bibliography}

Albert H. Y. Chen, The Interpretation of the Basic Law-Common Law and Mainland Chinese Perspectives (Hong Kong Journal Ltd 2000).

Andi Hamzah, Asas-Asas Hukum Pidana (2nd edn, Rineka Cipta 1994).

Aris Hardinanto, 'Manfaat Analogi Dalam Hukum Pidana Untuk Mengatasi Kejahatan Yang Mengalami Modernisasi’ (2016) 31 Yuridika.

Barda Nawawi Arief, Kebijakan Hukum Pidana; Perkembangan Penyusunan Konsep KUHP Baru (Kencana Prenada Media Group 2014).

Bisariyadi, 'Penafsiran Konstitusi Dalam Pengujian Undang-Undang Terhadap UUD' (2016).

Constitutional Court No. 46/PUU-XIV/2016 2017453.

Dramanda W, 'Menggagas Penerapan Judicial Restraint Di Mahkamah Konstitusi' (2014) XI Jurnal Konstitusi.

Faiz PM, 'Dimensi Judicial Activism Dalam Putusan Mahkamah Konstitusi' (2016) XIII Jurnal Konstitusi.

__ 'Judicial Restraint Vs Judicial Activism' [2017] Mahkamah Konstitusi 8.

Fat-Ash, 'Putusan MK Berpengaruh Pada Hukum Waris' Hukum Online (Jakarta, 
February 2012).

Kristian Erdianto, 'Mahfud MD: Yang Kurang Paham, Menuduh MK Perbolehkan Zina Dan LGBT' (Kompas, 2017) <https://nasional.kompas.com/ $\mathrm{read} / 2017 / 12 / 17 / 16235281 / \mathrm{mahfud}-m d-y a n g-k u r a n g-p a h a m-m e n u d u h-m k-$ perbolehkan-zina-dan-lgbt?page=all $>$ accessed 13 January 2018 .

Lalu Nugraha, 'Juridical Analysis of MK Decision No: 46/PUU-XIV/2016 Concerning Expansion of Zina and LGBT Meanings' (2018) 2 International Journal of Humanities, Religion and Social Science.

M.Saleem Ahmed Vignesh, 'A Study on Judicial Activism and Judicial Restraint in Indian Judiciary’ (2017) XX Humanities and Social Science.

Muchamad Ali Safa'at, 'Penafsiran Konstitusi' (2011).

Nanang Sri Darmadi, 'Kedudukan Dan Wewenang Mahkamah Konstitusi Dalam Sistem Hukum Ketatanegaraan Indonesia' (2015) 2 Pembaharuan Hukum.

Rosjidi Ranggawidjaja, Wewenang Manafsirkan Dan Mengubah Undang-Undang Dasar (Citra Bakti Akademika 1996).

Satjipto Rahardjo, Ilmu Hukum (Citra Aditya Bakti 2006).

Sudikno and A. Pitlo Mertokusumo, Bab-Bab Tentang Penemuan Hukum (Citra Aditya Bakti 1993).

Weldy Agiwinata, 'Konvensi Ketatanegaraan Sebagai Batu Uji Dalam Pengujian Undang Undang Di Mahkamah Konstitusi’ (2014) 29 Yuridika.

Yasmine Aulia, 'Kronologi Penangkapan Sepasang Muda-Mudi Mesum Di Dalam Masjid Di Tuntang' Tribun Jateng (Semarang, April 2018).

HOW TO CITE: Ansori and Muhammad Fuad Zain, 'Analysis of the Constitution Court Verdict Number 46/Puu-Xiv/2016 About Morality Criminal' (2019) 34 Yuridika. 